\title{
Correction to: Experimental Examination of the Behavior of Shotcrete-Reinforced Masonry Walls and Xgboost Neural Network Prediction Model
}

\author{
Melda Alkan Çakıroğlu ${ }^{2}$ Gülhan İnce ${ }^{3} \cdot$ Hamide Tekeli Kabas ${ }^{4}$ • Ahmet Ali Süzen ${ }^{1}$ (b)
}

Published online: 25 May 2021

(c) King Fahd University of Petroleum \& Minerals 2021

\section{Correction to:}

\section{Arab J Sci Eng}

https://doi.org/10.1007/s13369-021-05466-1

In the original publication, the order of author names was published wrongly. It should be "Melda Alkan Çakıroğlu² . Gülhan İnce ${ }^{3}$. Hamide Tekeli Kabas ${ }^{4}$. Ahmet Ali Süzen" ${ }^{1}$ ". The original publication has been updated of the same.

The original article can be found online at https://doi.org/10.1007/ s13369-021-05466-1.

Ahmet Ali Süzen

ahmetsuzen@isparta.edu.tr

Melda Alkan Çakıroğlu

meldacakiroglu@isparta.edu.tr

Gülhan İnce

gulhanince@mehmetakif.edu.tr

Hamide Tekeli Kabas

hamidetekeli@gmail.com

1 Department of Computer Technologies, Isparta University of Applied Sciences, Isparta, Turkey

2 Department of Civil Engineering, Isparta University of Applied Sciences, Isparta, Turkey

3 Department of Civil Engineering, Mehmet Akif Ersoy University, Burdur, Turkey

4 Department of Civil Engineering, Suleyman Demirel University, Isparta, Turkey 